\title{
Quantitative analysis of Operational Risk and Profitability of Kenyan Commercial Banks using Cost Income Ratio
}

\author{
Dr.Jane Gathigia Muriithi ${ }^{1}$ and Dr. Robert Gitau Muigai ${ }^{2}$ \\ ${ }^{I}$ School of Business, Jomo Kenyatta University of Agriculture and Technology, Kenya \\ ${ }^{2}$ School of Business, Kirinyaga University, Kenya
}

\begin{abstract}
The objective of this study was to analyse the effect of operational risk on profitability of commercial banks in Kenya. Operational risk was measured by cost income ratio while profitability by return on equity. The period of interest was between year 2005 and 2014 for all the 43 registered commercial banks in Kenya. Data was obtained from commercial banks' annual financial reports filed with the Central Bank of Kenya. Panel data techniques of random effects estimation and generalized method of moments (GMM) were used to purge timeinvariant unobserved firm specific effects and to mitigate potential endogeneity problems. Wald and F- tests were used to determine the significance of the regression while the coefficient of determination, within and between, was used to determine how much variation in dependent variable is explained by independent variable. Findings indicate that cost income is negatively associated with bank profitability both in long run and short run. Hence operating cost management is required to be given more attention by the commercial banks' management.
\end{abstract}

Keywords: Operational Risk, Cost Income ratio, profitability, Kenya

JEL Classification: G21, G31, O16, Z23

\section{Introduction}

Operational risk is considered as one of the serious concern and challenge for the modern banks. Basel Committee on Bank Supervision (2006) defines operational risk as the risk of loss resulting from inadequate or failed internal processes, people and systems or from external events. This definition includes legal risk which is the loss that arise from events such as internal and external fraud, employment practices and workplace safety clients, products and business practices, damage to physical assets, business disruption and system failures, and execution, delivery and process management. These events may cause operational losses which is associated with weaknesses of internal controls or failure to comply with existing internal procedures. Hence operational losses are cost to the bank that is generated by operational risk. If operational risk is not addressed systematically it can result into inconsistent performance and earnings for the stakeholders. Thus, operational risk exposures threatens the financial stability and performance of banking sector.

The paper employs a quantitative approach to identify how the operational risk affect the profitability of the Kenyan commercial banks. Cost to income ratio was used as the proxy for operational risk while returns on equity measured the profitability. Operational risk may materialize directly, for instance, in electronic fund transfer (transfer of funds to the wrong person) or could result indirectly as a credit or market loss. Since there is a close linkage of operational risk with other types of risks, it is very important for every institution to first have a clear understanding of the concept of operational risk before designing the appropriate operational risk measurement and management framework (Epetimehin and Obafemi, 2015).

\section{Literature Review}

Santomero (1997) explained operational risk relates to the issues of precisely processing, settling and taking delivery on trades for the exchange of cash. It also involves the record keeping, processing system failures and fulfillment of the diversified regulations. So that, individual operating problem is small portion for a well-managed institution but causes effect which may be quite costly. Goldmann et al., (2009) explained that internal fraud being operational risk is committed by both employees and management and accounts for $50-80 \%$ of frauds committed in organizations. Employees have access to information, processes, systems and assets therefore making it easier for them to device ways of committing fraud without being detected.

Tripe (1998) demonstrates how an operational risk capital charge (economic capital allocation) might be linked to volatility in the cost-to-income ratio, using a multiple of the standard deviation of the ratio. Tripe (1998) also shows how volatility in other measures, such as cost-to-assets, could be used to produce an economic capital charge. As explained by Tripe, different cost-based ratios produce significantly different capital charges. 
Francis and Hess (2004) examined how cost income ratio benchmarking was used by ASB Bank, a New Zealand-based retail bank, between when reviewing its operational efficiency. The study was conducted between August to November 2002. The research revealed that though the cost income ratio was the principal metric used in this benchmarking exercise, it sought to identify best practice not in terms of minimizing this ratio but rather in terms of identifying typical ratios and cost structures among successful banking institutions. The study observed that there is an inverse relationship between the cost income ratio and the bank's profitability

Mathuva (2009) examines the relationship between Capital Adequacy, Cost Income Ratio and the profitability of Kenyan Commercial Banks. The study used the return on assets and the return on equity as proxies for bank profitability for the period 1998 to 2007. The data was obtained from the annual financial statements for a selected sample of 41 out of the 44 licensed commercial banks in Kenya by CBK in year 2008. The study finds out that Kenyan banks are not competitive enough globally in terms of their efficiency as measured by the Cost-Income Ratio (CIR). The study reveals that the CIR being a measure of operational risk is inversely related return on assets and return on equity. The study shows that the cost-income ratio is negative and strongly significant with profitability measures, indicating that more efficient banks generate higher profits. The study also reveals that the CIRs of Kenyan banks are higher than those of developed countries. The current study differ from this study because it employs the GMM method to check the dynamism in the banking sector.

Kimani (2011) assessed fraud risk for Barclays Bank of Kenya and found that bank's statistics show that the frequency of internal fraud is increasing drastically and has by far inflicted the most significant losses to the bank. This is because some dishonest employees and managers have found ways to override systems and or collude with outsiders to defraud the bank. According to the Bank's fraud unit, management fraud occurs less frequently but accounts for the greatest financial losses. Position equals power; managers and executives, having more access to more information and assets than regular employees and can commit fraud relatively easier without being noticed.

Al-Tamimi et al., (2015) examined the relationship between financial risk and performance of Gulf Cooperation Council Islamic banks and the relative importance of the most common types of risk. The study covered 11 of the 47 Islamic banks of the Gulf Cooperation Council region from 2000 to 2012. Regression analysis indicated that there exists a significant negative relationship between the Gulf Cooperation Council Islamic banks' performance, capital risk and operational risk. Capital risk was the most important type of risk and then followed by operational risk.

Muriithi and Waweru (2017) employs a qualitative approach to identify how the causes of a loss event affects the returns of the shareholders of Kenyan commercial banks. The qualitative research design and ordered logistic model were employed. The dependent variable financial performance was measured by return on equity. The dimensions of operation risk were four namely internal and external fraud (IEF), clients, products and business practices (CPBP), business disruption and system failure (BDSF) and execution, delivery and process management (EDPM). The findings were that operational risk negatively affects the financial performance

\subsection{Research design}

\section{Methodology Framework}

The study employed Time Series Cross Sectional (TSCS) research design to analyse the relationship between the operational risk and profitability of Kenyan commercial banks. Operational risk and profitability were measured by cost income ratio and return on equity respectively. Stimson (1985) explained that TSCS designs have long been considered as one of the best designs for the study of causation, next to a purely random experiment and TSCS research design is a quasi-experimental research design. The study used financial ratio analysis and unbalanced panel data regression analysis to measure, describe and analyse the effect of the operational risk on the profitability of commercial banks in Kenya during the period 2005-2014. Panel data estimation techniques of random effects estimation and generalized method of moments (GMM) was adopted because it takes care of heterogeneity associated with individual banks by allowing for individual specific variables.

The researcher employed a census study as secondary data for all the 43 licensed commercial banks in Kenya was collected and analyzed. The long run specification was estimated using the fixed effects or random effects models while the short run model was estimated using system Generalized Methods of Moments (GMM) estimator as put forward by (Verbeek, 2004). The Estimation of the short run model were to be preceded by the estimation of the naïve OLS and fixed effects models to establish the required bound for coefficient of lagged bank performance as put forth by (Roodman, 2006).

To establish the reliability of the estimates a number of post estimation diagnostics were to be interpreted. The fixed and random effect model involved interpretation of the F statistic, interclass correlation (rho), within and between R-square, chow test statistics, LM test statistic and Hausman test. The short run GMM specification involved the interpretation of Hansen $\mathbf{J}$ statistic and the Arrelano and Bond autocorrelation tests 


\subsection{Model specification}

Objective of this paper was to establish whether operational risk affects the profitability of the commercial banks in Kenya. The study assumed that the independent variable and the dependent variable have a general multiplicative Cobb Douglas functional relationship shown in equation 1

$R O E=f(C I R)$

Upon linearization and parametization the long run model for functional form 1 was specified as:

$\boldsymbol{R O E}_{i t}=\lambda_{\mathrm{O}}+\lambda_{1} \mathrm{CIR}_{i, t}+\theta_{i}+\varepsilon_{i, t}$

And the short run model as:

$R O E_{i t}=\lambda_{0}+\beta R O E_{t-1}+\lambda_{1} C I R_{i, t}+\theta_{i}+\varepsilon_{i, t}$

In which $\mathrm{ROE}_{\mathrm{i}, \mathrm{t}}$ represents the profitability of bank $i$ at time $t, \lambda_{0}$ stands for the model constant or intercept, $\lambda_{i}$ stands for the coefficients of the independent variable. $R O E_{i t-1}$ is lagged bank profitability, $\mathrm{CIR}_{\mathrm{i}, \mathrm{t}}$ is the Cost Income ratio of bank $i$ at time $\mathrm{t}$, and $\varepsilon_{\mathrm{i}, \mathrm{t}}$ is the error term which is assumed to have a normal distribution. $\theta_{i}$ is the bank specific effect that is assumed to be normally distributed with a constant variance $\varepsilon_{i t}$ is the idiosyncratic error term which is assumed to have a normal distribution.

\subsection{Measurement of Cost Income Ratio}

The measure of cost income is indirectly related to bank profitability because it comprises of cost and income in a specific period. The cost to income ratio is also known as the Efficiency Ratio. A reduction in costs for a given level of income is expected to increase profits and vice versa. Increased profits, in turn, will result in improved return on equity and share prices of the bank. The cost to income ratio is the ratio of non-interest (operating) costs excluding bad and doubtful debt to the net interest income plus non-interest income of the bank. Non-interest costs are as those costs which are incurred during the operations by the management and staff, these costs can be controlled. The use of the net interest income term in the denominator will reduce the volatility that could arise from fluctuations in the general level of interest rates (Correa and Raju, 2008).

Cost Income ratio $=\frac{\text { Operating Cost }}{\text { Income }}$

4.01 Summary statistics of the data

\section{Data Analysis And Results}

Table 1: Summary Statistics

\begin{tabular}{|l|l|l|c|l|l|}
\hline Variables & $\mathrm{N}$ & Mean & Standard Deviation & Min & Max \\
\hline ROE & 416 & 0.178 & 0.170 & -0.909 & 0.500 \\
\hline CIR & 414 & 0.561 & 0.214 & 0.045 & 1.60 \\
\hline
\end{tabular}

Table 1 shows that the number of observations per each variable varied. This may be explained by the unbalanced nature of the panel data used in the analysis. The mean of ROE of 17.8 per cent is an indication that banks are competing among them for making profit however their standard deviations of 17.0 percent evident that their profit making capacity is divergent from each other. Findings indicate that the mean cost income was 56.1 percent with a corresponding standard deviation of 0.214 .

4.02 Skewness, Kurtosis and Normality Test of One Way Error Component for panel Models

The extension of the Bera-Jarque normality test by Galvao, Montes-Rojas, Sosa-Escudero and Wang (2013) made the normality test a standard test that can be performed prior to the estimation of the model or even after the estimation of the model. The normality test of each of the components in the error term is shown in table 2 for each model.

Table 2: Skewness Kurtosis and Normality of One way Error component for Panel Model

\begin{tabular}{|c|c|c|c|c|c|c|c|}
\hline \multicolumn{2}{|c|}{} & \multicolumn{2}{c|}{ Skewness } & \multicolumn{2}{c|}{ Kurtosis } & \multicolumn{2}{c|}{ Normality } \\
\hline \multirow{2}{*}{ Model } & Error Component & Z Statistic & P-Value & Z Statistic & P-Value & Chi Statistic & P-Value \\
\hline \multirow{2}{*}{1} & $\mathrm{e}$ & 1.08 & 0.278 & 1.65 & 0.071 & 8.80 & 0.0623 \\
\cline { 2 - 9 } & $\mathrm{u}$ & 1.74 & 0.081 & 0.98 & 0.353 & 3.90 & 0.1421 \\
\hline
\end{tabular}

Table 2 shows the distribution of the one-way error component in the linear panel model 1 . The individual specific heterogeneity component is e while $\mathrm{u}$ is the error term. $\mathrm{u}$ varies with banks only while $\mathrm{e}$ varies across banks and time. To use the variance of the combined error term to test the significance of the coefficients in the estimates of the model requires that each component is normally distributed. Therefore, the 
skewness and kurtosis of the components should be symmetrical to that of the normal distribution. Table 2 shows that the $\mathrm{z}$ statistic for the skewness of the component in model 1 have $\mathrm{z}$ statistic with corresponding $\mathrm{p}$ values that are greater than 0.01. Thus, the $\mathrm{Z}$ statistic is less than the tabulated at five per cent level of significance. Therefore, the null hypothesis of symmetrical skewness with normal distribution is not rejected. Thus, the component is neither negatively nor positively skewed compared to the normal distribution.

The test further shows that the $\mathrm{z}$ statistic for kurtosis of the component of the error term in the model has p-value greater than 0.1. Therefore, the $\mathrm{z}$ statistic is less than the tabulated statistic at five per cent level of significance. Thus, the null hypothesis that each component kurtosis is symmetric to that of the normal distribution is not rejected at five per cent level of significance. Therefore, the component of the error term is neither more nor less peaked than the normal distribution. The overall normality test of each component of the error term in model 1 has chi statistics with corresponding p-value that are greater than 0.1. Therefore, the chi statistic is less than the critical value at five per cent level of significance. Thus, the null hypothesis that the component is normally distributed is not rejected at five per cent level of significance. Therefore, the error component is normally distributed for model 1 . The fact that the one-way error component model is normally distributed in model 1 implies that the study could reliably use the standard errors and $t$-statistics. The use of standard errors and $t$ statistics to test for the significance of coefficient is based on Gaussianicity of the error term. An assumption satisfied by the errors from the panel data model.

\subsection{Effect of operational risk on profitability of commercial banks}

To test the hypothesis the long run and the short run version of model 1 were estimated. The first long run specification of model 1 was the fixed effects model whose findings are shown in table 3 .

Table 3: Model 1 Fixed Effects Estimates

\begin{tabular}{|c|c|c|}
\hline \multicolumn{2}{|l|}{ Dependent variable } & ROE \\
\hline \multicolumn{2}{|l|}{ Explanatory Variable } & Coefficient \\
\hline \multicolumn{2}{|l|}{ CIR } & $-0.337 * * *$ \\
\hline \multicolumn{2}{|l|}{ Constant } & $0.090 * * *$ \\
\hline \multicolumn{3}{|c|}{ Post Estimation Diagnostics } \\
\hline \multirow[t]{4}{*}{ R square } & Within & 0.3759 \\
\hline & Between & 0.4093 \\
\hline & Overall & 0.3719 \\
\hline & Rho & 0.6901 \\
\hline \multicolumn{2}{|l|}{ F test $(1,338)$} & $203.61 * * *$ \\
\hline chow test & $\mathrm{F}(41,320)$ & $19.64 * * *$ \\
\hline \multicolumn{3}{|c|}{ KEY } \\
\hline p-value $<0.01$ & & $* * *$ \\
\hline $\mathrm{P}$-value $<0.05$ & & $* *$ \\
\hline $\mathrm{P}-$ value $<0.1$ & & $*$ \\
\hline
\end{tabular}

Table 3 shows that the F statistic is 203.61 and is greater than the critical value at one per cent level of significance. Therefore, the variable is significant in explaining the variations in return on equity. The interclass correlation (rho) is 69.01 per cent implying that 69.01 per cent of the variations in return on equity are due to differences across the banks. The within and between R-square is 37.59 per cent and 40.93 per cent respectively. Thus, 37.59 per cent of variations in the return on equity are due to differences within individual banks and 40.93 per cent of the variations are due to differences between the banks. The overall $\mathrm{R}^{2}$ is 37.19 percent, indicating that the variable (CIR) considered in the model account for about 37 percent change in the dependent variables, while about 63 percent change may be as a result of other variables not addressed by this model.

The chow test statistic is $\mathbf{1 9 . 6 4}$ and is greater than the critical value at one per cent level of significance. Therefore, the null hypothesis that the fixed effects are equal to zero is rejected at one per cent level of significance. Thus the option of specifying the model as a pooled OLS model over the Fixed effects specification is rejected at one per cent level of significance. The second alternative specification of model 3 is the random effects model whose findings are shown in table 4. 
Table 4: Model 1 Random Effects Estimates

\begin{tabular}{|c|c|c|}
\hline \multicolumn{2}{|l|}{ Dependent variable } & ROE \\
\hline \multicolumn{2}{|l|}{ Explanatory Variable } & Coefficient \\
\hline \multicolumn{2}{|l|}{$\mathrm{CIR}$} & $-0.345 * * *$ \\
\hline \multicolumn{2}{|l|}{ Constant } & $0.082 * * *$ \\
\hline \multicolumn{3}{|c|}{ Post Estimation Diagnostics } \\
\hline \multirow[t]{4}{*}{ R square } & Within & 0.3759 \\
\hline & Between & 0.4093 \\
\hline & Overall & 0.3719 \\
\hline & Rho & 0.6732 \\
\hline \multicolumn{2}{|l|}{ Wald test $(1,338)$} & 228.83 *** \\
\hline Lm test & Chibar2 & $700.06^{* * * *}$ \\
\hline \multicolumn{3}{|c|}{ KEY } \\
\hline \multicolumn{2}{|l|}{$\mathrm{p}$-value $<0.01$} & **** \\
\hline \multirow{2}{*}{\multicolumn{2}{|c|}{$\frac{P \text {-value }<0.05}{\mathrm{P}-\mathrm{v} / \mathrm{l}}<01$}} & ** \\
\hline & & * \\
\hline
\end{tabular}

Table 4 shows that the Wald statistic is 228.83 and is greater than the critical value at one per cent level of significance. Therefore, the independent variable is significant in explaining the variations in return on equity in the random effects specification. The interclass correlation (rho) is 67.32 per cent implying that 67.32 per cent of the variations in return in equity are due to differences across the banks as per the random effects model. The coefficient of determinations, R-square shows the within and between values of 37.59 per cent and 40.93 per cent respectively. Thus, 37.59 per cent of variations in the return on equity are due to differences within individual banks and 40.93 per cent of the variations are due to differences between the banks.

The LM test statistic is 700.06 and is greater than the critical value at one per cent level of significance. Therefore, the null hypothesis that the cross sections are not heterogeneous is rejected at one per cent level of significance. Thus the random effects specification is preferred over pooled OLS.

A comparison of the post estimation diagnostics between the Fixed and random effects specification reveals that the conclusions are comparable. For instance when POLS specification is compared with the estimated models it's rejected in both instances. In addition the overall explanatory powers of the specifications are not significantly different; both fixed and random effect specifications explain an overall explanation 37 per cent. However, the consistency in post estimation diagnostics does not eliminate the need to discriminate between the models. The Hausman test statistics to discriminate between the specifications are shown in table 4.30.

Table 5: Model 1 Hausman Test

\begin{tabular}{|c|c|}
\hline Test statistic Chi(1) & P-value \\
\hline 1.75 & 0.1855 \\
\hline
\end{tabular}

Table 5 shows that the test statistics have a chi statistic of 1.75 with one degree of freedom and a corresponding $\mathrm{p}$ value of 0.1130 . Therefore, the null hypothesis that the regressors and individual heterogeneity are strictly exogenous is not rejected at one per cent level of significance. Thus the RE specification is preferred over FE specification. Therefore, for the long run specification the random effects model should be interpreted. To establish the bound where the coefficient of lagged profits would lie the naïve OLS was estimated. The OLS estimates over state the coefficient of lagged profits by attributing to it some explanatory power of the error term. Thus the OLS estimate provides the upper bound of the coeffient. The OLS estimates are shown in table 6.

Table 6: OLS Estimates for operational risk component

\begin{tabular}{|l|c|}
\hline Dependent variable & ROE \\
\hline Explanatory Variable & Coefficient \\
\hline$R O E_{t-1}$ & $0.434^{* * *}$ \\
\hline CIR & $-0.254^{* * *}$ \\
\hline Constant & $0.034^{* * *}$ \\
\hline \multicolumn{2}{|c|}{ Post Estimation Diagnostics } \\
\hline R square KEY & 0.626 \\
\hline F statistic $(2,343) \quad$ 287.08** \\
\hline $\begin{array}{l}\text { p-value }<0.01 \\
\text { P-value }<0.05\end{array}$ & $* * *$ \\
\hline $\mathrm{P}-$ value $<0.1$ & $* *$ \\
\hline
\end{tabular}

Table 6 shows that the coefficient of lagged return on equity is 0.434 . Therefore, the upper bound for the coefficient of lagged return on equity in the GMM specification of the short run model should be 0.434 . To 
get the lower bound the fixed effect estimates of the short run specification are used. Fixed effect estimation understates the coefficient by denying the lagged dependent variable some of its explanatory power, thus providing the lower bound. The fixed effect estimates of the short run specification are shown in table 7.

Table 7: Fixed Effects Estimates for operational risk component

\begin{tabular}{|l|c|}
\hline Dependent variable & ROE \\
\hline Explanatory Variable & Coefficient \\
\hline$R O E_{t-1}$ & $0.115^{* * *}$ \\
\hline CIR & $-0.308^{* *}$ \\
\hline Constant & $0.079^{* * *}$ \\
\hline \multicolumn{2}{|c|}{ Post Estimation Diagnostics } \\
\hline R square & 0.5115 \\
\hline F statistic $(2,302) \quad$ KEY & $93.83^{* * *}$ \\
\hline \multicolumn{2}{|c|}{$\mid * * *$} \\
\hline p-value $<0.01$ & $* *$ \\
\hline P-value $<0.05$ & $*$ \\
\hline P - -value $<0.1$ & \\
\hline
\end{tabular}

Table 7 shows the fixed effects estimates of the short run specification of model 1 . The coefficient of lagged return on equity is 0.115 . Thus the lower bound of lagged return on equity in the GMM specification should be 0.115 . Specifically if the estimate is $\lambda$, it should lie in the interval $0.115 \leq \lambda \leq 0.434$. To obtain consistent estimates of the short run spefication one step system GMM is used. The estimates are shown in table 8.

Table 8: One Step System GMM Estimates

\begin{tabular}{|c|c|}
\hline Dependent variable & ROE \\
\hline Explanatory Variable & Coefficient \\
\hline$R O E_{t-1}$ & $0.210 * * *$ \\
\hline CIR & $-0.446^{* * *}$ \\
\hline Constant & $0.009 * * *$ \\
\hline \multicolumn{2}{|c|}{ Post Estimation Diagnostics } \\
\hline Hansen $\mathrm{J}$ test & 38.22 \\
\hline $\mathrm{AR}(1)$ & $-3.60 * * *$ \\
\hline $\mathrm{AR}(2)$ & -0.60 \\
\hline \multicolumn{2}{|c|}{ KEY } \\
\hline p-value $<0.01$ & $* * *$ \\
\hline P-value $<0.05$ & *** \\
\hline $\mathrm{P}-$ value $<0.1$ & $*$ \\
\hline
\end{tabular}

Table 8 shows the one step system GMM estimates for the short run specification of model 1 . The table shows that the coefficient of the lagged return on equity is 0.210 . The coefficient, therefore, lies in the acceptable range of $0.115 \leq \lambda \leq 0.434$ etablished by the naïve OLS estimates and fixed effects estimates of the short run model 1 . Hence consistency of model estimates.

Table 8 further shows that the Hansen $\mathbf{J}$ statistic is 38.22 with a corresponding p-value greater than 0.1 . Therefore, the null hypothesis of the validity of the overidentifying restrictions for the instruments is not rejected at one per cent level of significance. Therefore, the instruments employed by the model are appropriate and lead to precise consistent estimates.

In addition table the resultsshows that the test of autocorrelation in the error terms. The AR(1), first order autocorrelation, test statistic is -3.60 and is greater than the critical value at one per cent level of significance. Therefore the null hypothesis that disturbance term (error terrm) has no first order serial correlation is rejected at one per cent level of significance. This is expected because of the dynamic specification of model 1 and therefore, points to correct specification. The test statistic for second order serial correlation in the error term is -0.60 with a coreresponding $\mathrm{p}$-value that is greater than 0.1 . Therefore, at one per cent level of significance the null hypothesis that there is no second order serial correlation in the disturbance term is not rejected at one per cent level of significance. This permits the use of insturments from the second lag and differences further supporting the argument of correct short run specification of model 1 using the one step GMM estimates.

To Summarize the findings necessary to test the forth hypothesis in the short run and in the long run. The findings in table 3 through 8 are summarized in table 9 . 
Quantitative analysis of Operational Risk and Profitability of Kenyan Commercial Banks using Cost ..

Table 9: Effect of Operational risk on profitability of Commercial Banks in Kenya

\begin{tabular}{|c|c|c|c|c|c|}
\hline \multirow[b]{2}{*}{ Variables } & \multicolumn{2}{|c|}{ Long Run Model } & \multicolumn{3}{|c|}{ Short Run Model } \\
\hline & Fixed Effects & Random Effects & OLS & Fixed Effects & GMM \\
\hline \multirow{2}{*}{$R O E_{t-1}$} & & & $0.434 * * *$ & $0.115 * * *$ & $0.210 * *$ \\
\hline & & & $(0.0286)$ & $(0.0298)$ & $(0.0896)$ \\
\hline \multirow[t]{2}{*}{ CIR } & $-0.337 * * * *$ & $-0.345 * * *$ & $-0.254 * * *$ & $-0.308 * * *$ & -0.446 *** \\
\hline & $(0.0237)$ & $(0.0228)$ & $(0.0233)$ & $(0.0246)$ & $(0.0766)$ \\
\hline \multirow[t]{2}{*}{ Constant } & $0.090 * * *$ & $0.0821 * * *$ & $0.0345 * * *$ & $0.0787 * * *$ & $0.009^{* * * *}$ \\
\hline & $(0.009)$ & $(0.0142)$ & $(0.009)$ & $(0.0106)$ & $(0.0298)$ \\
\hline Observations & 381 & 381 & 346 & 319 & 346 \\
\hline R-squared & 0.376 & & 0.626 & 0.383 & \\
\hline Hausman Chi(1) & \multicolumn{2}{|c|}{1.75} & & & \\
\hline Wald statistic & & $228.83^{* * *}$ & & & \\
\hline F statistic & $203.61 * * *$ & & $287.08 * * *$ & $93.83 * * *$ & $31.53^{* * *}$ \\
\hline $\begin{array}{l}\text { KEY: } \\
\text { ROE represent ret }\end{array}$ & $\begin{array}{l}\text { ors in parenth } \\
* * \mathrm{p}<0.05, * \\
\text { CIR represe }\end{array}$ & & & & \\
\hline
\end{tabular}

The long run and short run estimates on the effect of operational risk on profitability of commercial banks in Kenya are shown in table 9. It shows that in the long run the coefficient of cost to income ratio (CIR) is -0.345 with a $\mathrm{p}$ value less than 0.01 . Thus, the coefficient is significantly different from zero at one per cent level of significance. Therefore, the hypothesis that CIR has a negative significant effect on profitability of commercial banks in Kenya is not rejected at one per cent level of significance. The magnitude of the coefficient is 0.345 . This means that one per cent increase in CIR decreases return on equity by 34.5 percentage points in the long run holding other factors constant. In the long run the Wald statistic is 228.83 and is greater than the critical value at one per cent level of significance. Therefore, in the long run hypothesis that operational risk has a significant effect on the profitability of commercial banks in Kenya is not rejected at one per cent level of significance.

In the short run the coefficient of CIR is -0.446 with a p-value less than 0.01 . Therefore, the coefficient is significant at one per cent and negative. Thus in the short run the hypothesis that CIR has a significant negative effect on profitability of commercial banks in Kenya is not rejected at one per cent level of significance. The magnitude of the coefficients is 0.446 . Thus in the short run a one per cent increase in CIR causes a 44.6 percentage points decrease in the profitability of commercial banks in Kenya holding other factors constant. In the short run the F statistic is 31.53 and is greater than the critical value at one per cent level of significance. Thus in the short run hypothesis four, CIR has a significant effect on the profitability of commercial banks in Kenya is not rejected at one per cent level of significance. Thus operational risk influences profitability of commercial banks in Kenya both in the short run and in the long run.

Consistent with (Al-Tamimi et al., 2015 and Mathuva, D. M., 2009) that CIR has a negative and strongly significant effect of profitability. This is an indication that operational efficiency in commercial banks is low. The income comprises net interest income, fee income, trading income, and other non-interest income. The cost comprises staff, rental, information technology, and other operating expenses. Thus reduction in CIR means lowering the costs or increasing the income will translate to greater efficiency. However, there should be some critical threshold at which the relationship between costs and income as embodied in the ratio as such operational risk cannot be fully eliminated. For instance, considering reducing the cost income ratio from reporting period can result in a bank reducing discretionary expenditures in audit, personnel, marketing and monitoring systems which they all impact operational risk directly and adversely. Alternatively, non-interest income sources, such as insurance and funds management impact cost-to-income ratio positively. Lack of skills and product knowledge may also increase the cost income ratio. Frauds have increased drastically in Kenyan commercial banks and inflicted the most significant losses to the bank (Kimani, 2011). Also bank supervision annual report 2014 from CBK indicates that cases relating to computer, mobile and internet banking are on the rise. Other fraud cases such as card fraud have also been attributed to computer-based on line transactions which do not have effective preventive and detective controls. Hence more research on operational risks are required so as to help the banks put in place effective operational risk management and control processes.

\section{Discussion and Recommendations}

The study indicated that there existence operational risk which is mainly related to costs leading to uncertainty regarding a financial bank's earnings. This is as a result of failures in computer systems, error, misconduct by employees, or risk of loss due to operating expenses. This brings a great concern to the society, the government and the bank itself. It is critical for measures to be taken to prevent the occurrence of operational risks in Kenyan banks given the important roles banks play in the nation's economy. Larger 
commercial banks incur high costs which may lead to high profitability. For instance, improvement of technology and systems may increase the cost as well as the profitability.

In the view that operational risk has significant impact on profitability, the recommendation is that each Kenyan bank must improve its operational risk management processes as it is in line with the proposal in the new Basel Capital Accord, banks are required to provide capital for operational risk. These operational risk management and control processes, should cover the design, implementation and review of operational risk methodology. The banks' internal audit groups are expected to conduct regular reviews of the operational risk management involvement of the board of directors, and senior management of banks are expected in risk management. Hence guidelines and procedures provided by the CBK on operational risk management should be fully adhered into to ensure the risk is well mitigated and improvement in profitability.

\section{References}

[1]. Al-Tamimi, H., Hussein, A., Miniaoui, H., \& Elkelish, W. W. (2015). Financial Risk and Islamic Banks' Performance in the Gulf Cooperation Council Countries. The International Journal of Business and Finance Research, 9(5), 103-112.

[2]. Baltagi, B. H. (2005). Econometric analysis of panel data (3rd ed). Chichester; Hoboken, NJ: J. Wiley \& Sons

[3]. Basel Committee on Banking Supervision (BCBS) (2006). Basel II: International Convergence of Capital Measurement and Capital Standards: A Revised Framework - Comprehensive Version. . Available online: http://www.bis.org/publ/bcbs128.htm (accessed on 24 Dec 2016)

[4]. Correa, R., \& Raju, S. (2008). Operational risk measurement for the Indian banking sector: Alternative measures. University of Mumbai (Department of Economics)

[5]. Epetimehin F. M., \& Obafemi F. (2015). Operational risk management and the financial sector development: An overview. International Journal of Economics, Commerce and Management. United Kingdom Vol. III (3), http://ijecm.co.uk/

[6]. Goldmann, \& Kaufman, H. (2009). Anti-fraud risk and control workbook. John Wiley \& Sons.

[7]. Francis, G. \& Hess, K. (2004). Cost income ratio benchmarking in banking: a case study. Benchmarking: An International Journal, 11(3), 303-319.

[8]. Kimani, J. (2011). Fraud Risk Assessment Plan for Barclays Bank of Kenya. Tampere University of Applied Sciences.

[9]. Mathuva, D. M. (2009). Capital adequacy, cost income ratio and the performance of commercial banks: The Kenyan Scenario. The International journal of applied economics and Finance, 3(2), 35-47.

[10]. Mugenda, O. \& Mugenda. A.(2003). Research methods: quantitative and qualitative approaches.

[11]. Muriithi J.G., and Waweru.K.M. (2017). Operational Risk, Bank Size and Financial Performance of Commercial Banks in Kenya.

[12]. Tripe, D. (1998). Cost to income ratios in Australasian banking. Department of Finance, Banking and Property, College of Business, Massey University.

[13]. Santomero, A. M. (1997). Commercial bank risk management: an analysis of the process. Journal of Financial Services Research, 12(2), 83-115.

[14]. Verbeek, M. (2004). A guide to modern econometrics (2nd ed). Southern Gate, Chichester, West Sussex, England Hoboken, NJ: John Wiley \& Sons.

[15]. Wooldridge, J., (2005), Econometrics Analysis of Cross Section and Panel data. Cambridge, Massachusetts. MIT Press 